\title{
Female maturation and rematuration acceleration of Mutiara strain catfish Clarias gariepinus using combination of oocyte developer hormone and astaxanthin addition diet
}

\section{Maturasi dan percepatan rematurasi ikan lele Mutiara Clarias gariepinus betina dengan kombinasi hormon Oodev dan suplementasi astaxanthin pada pakan}

\author{
${\text { Fatahillah Maulana Jufri }{ }^{*} \text {, Agus Oman Sudrajat }{ }^{2 *} \text {, Mia Setiawati }}^{2}$ \\ ${ }^{1}$ Marine and Fisheries Department of West Java Province \\ ${ }^{2}$ Aquaculture Department, Fisheries and Marine Science Faculty, IPBUniversity \\ *Corresponding author : fatahillah.spi@gmail.com, omanipb@gmail.com
}

(Received August 10, 2018; Accepted November 2, 2018)

\begin{abstract}
Reproductive design for gonadal maturation process mostly related with some factors such as environmental signals, reproductive organs, hormonal and nutrition. This research was conducted on female Mutiara strain of North African catfish, Clarias gariepinus by combining two kinds of materials administered to broodstock diet, namely oocyte developer (Oodev) which contains of PMSG hormone and antidopamin, and astaxanthin carotenoid. Research designs were divided into C (Control), A50 (astaxanthin $50 \mathrm{mg} / \mathrm{kg}$ feed), A100 (astaxanthin $100 \mathrm{mg}$ / $\mathrm{kg}$ feed), Od0.5 (Oodev $0.5 \mathrm{~mL} / \mathrm{kg}$ fish for two weeks), Od1 (1 mL/kg fish for 2 weeks), Od0.5A50 (combined Od0.5 with A50), Od1A50 (combined Od1 with A50), Od0.5A100 (combined Od0.5 with A100), and Od1A100 (combined Od1 with A100). This research was performed during twelve weeks of feeding. The Od1A100 treatment showed the best reproduction performance result compared to other treatment with highest hepatosomatic (HSI) and gonadosomatic $(\mathrm{HSI})$ indexes $(\mathrm{P}<0.05)$, also fastest increase in egg diameters $(\mathrm{P}<0.05)$, shorter rematuration periods and highest proportion of mature broodstock. These results indicated that Oodev and astaxanthin could accelerate gonadal maturity in female broodstock of Mutiara catfish.
\end{abstract}

Keywords: Broodstock, hormonal, reproduction, oocyte developer, astaxanthin

\begin{abstract}
ABSTRAK
Rekayasa reproduksi untuk proses pematangan gonad sebagian besar terkait dengan beberapa faktor seperti sinyal lingkungan, organ reproduksi, hormonal dan nutrisi. Penelitian ini dilakukan terhadap strain ikan lele Mutiara Clarias gariepinus betina menggunakan dua bahan yang dicampur pada pakan induk, yaitu oocyte developer (Oodev) yang mengandung hormon PMSG dan antidopamin, dan karotenoid astaxanthin. Eksperimen yang dirancang adalah $\mathrm{K}$ (Kontrol), A50 (Astaxanthin $50 \mathrm{mg} / \mathrm{kg}$ pakan), A100 (Astaxanthin $100 \mathrm{mg} / \mathrm{kg}$ pakan), Od0.5 (Oodev 0,5 mL/kg induk untuk 2 minggu), Od1 (Oodev $1 \mathrm{~mL} / \mathrm{kg}$ induk untuk $2 \mathrm{minggu}$ ), Od0.5A50 (kombinasi Od0.5 dan A50), Od1A50 (kombinasi Od1 dan A50), Od0.5A100 (kombinasi Od0.5 dan A100), dan Od1A100 (kombinasi Od1 dan A100). Penelitian ini dilakukan dengan memberi makan dua belas minggu. Performa reproduksi terbaik didapat pada perlakuan Od1A100. Od1A100 memiliki indeks hepatosomatik (HSI) dan gonadosomatik (HSI) tertinggi (P $<0,05)$, juga diameter telur paling cepat besar $(\mathrm{P}<0,05)$, periode rematurasi terpendek, dan proporsi induk matang gonad tertinggi. Hasil ini menunjukkan bahwa Oodev dan astaxanthin dapat mempercepat kematangan gonad pada induk betina ikah lele Mutiara.
\end{abstract}

Kata kunci: Induk, hormon, reproduksi, oocyte developer, astaxanthin 


\section{INTRODUCTION}

North African catfish Clarias gariepinus which is high economic value commodity, has been widely produced in Indonesia. According to Ministry of Marine Affairs and Fisheries (MMAF) of Indonesian Republic (2015), its production increased $37.13 \%$ yearly. The North African catfish production continues to grow as the increases demand on local and international markets, from 144.744 tons at 2009 become 679.376 tons at 2014. However, North African catfish production has been marked by scarcity of the seeds problems, caused by the gap between increased market demands which was not followed by increased in seeds supply because the seeds production is still very low. This is because North African catfish are like other tropical fish that breeding seasonally (Saadony et al., 2014), and only breeding during the rainy season (Dadebo $e t$ al., 2011).

Mutiara strain of the North African catfish (Clarias gariepinus) which has various superior traits including growth, feed efficiency, size homogeneity, and resistance to disease and environmental conditions originated from The Ministry of Marine and Fisheries Affairs breeding result also requires long time to get mature. According to Iswanto et al. (2016) the female Mutiara catfish start mature on 10 months old and after spawning the rematuraion needs 1.5 months like other African catfish. The maturation processes of $C$. gariepinus kept in outdoor ponds are influenced by annual changes in water temperature, photoperiodicity, and the final triggering of spawning is usually caused by a raise in water level due to rainfall (De Graaf \& Janseen, 1996).

Mature female $C$. gariepinus broodstock contains 15-20\% eggs of body weight if the water temperature is above $22^{\circ} \mathrm{C}$, however the oocyte development drop if the temperature dropped below $22^{\circ} \mathrm{C}$. At the peak of dry season (three months), water temperature dropped below $22^{\circ} \mathrm{C}$, causes the ovaries produce only $5 \%$ eggs of female broodstock body weight. In addition the number of eggs produced dropped and the quality of eggs produced are decreased, seen from the decreased hatching percentage (De Graaf \& Janseen, 1996). Therefore, even though North African catfish seeds can produced throughout the year, the optimal time of seed production is only nine months.
One way to get optimal fish breeding is by improving the reproductive performance through nutritional supplementation in the broodstock diet, which combined with hormonal rematuration induction (Nainggolan et al., 2014). Nutrient quality improvements of broodstock diet and the ability to store energy can determine fish maturation time (Mañanós et al., 2008), and the use of exogenous hormones is an effective way to induce maturation of eggs. Furthermore, hormonal manipulations can be used as management tools to enhance and synchronize egg maturation, spermiation and facilitate hatching operations in most fish culture (Mylonas et al., 2010).

The fish female reproductive cycle is separated in the growth (gametogenesis) and maturation phase (oocyte maturation), controlled by the reproductive hormones of the brain, pituitary and gonad. Although the growth phase of reproductive development concluded, in captivity, most fishes oocyte maturation (OM) and ovulation in females may require exogenous hormonal therapies (Mylonas et al., 2010). Maturation hormonal induction basically consists of two main principles: first by increasing the secretion of follicle stimulating hormone (FSH) of pituitary which will stimulate theca and granulose cells ovarian follicle to secrete sex steroid hormones estradiol-17 $\quad\left(\mathrm{E}_{2}\right)$ that promotes oogonial proliferation and vitellogenesis, and progestogens that promotes initiation of germ cell meiosis and follicular maturation and ovulation (Reading \& Sullivan, 2011). Secondly, by inhibiting the action of dopamine which acts as gonadotropin release inhibiting factor (GRIF) which can inhibit the release of FSH in oocyte maturation (Bryant et al., 2016). According to Dufour et al. (2010) combined treatment with gonadotrophin releasing hormone $(\mathrm{GnRH})$ agonist and anti-dopamine $(\mathrm{AD})$ as a new method to induce spawning in aquaculture.

Hormonal induction to accelerate gonadal maturation has been widely applied to broodstock fish. One of them by using Oodev (oocyte developer), a premix hormone which contains PMSG (pregnant mare serum gonadotropin) and $\mathrm{AD}$. The principle and function of this hormone premix are to stimulate a spike of GnRH level, which in turn will stimulate the pituitary to produce gonadotropin (Sudrajat et al., 2016). The study results showed that the use of Oodev combined with Spirulina platensis supplementation in North African catfish broodstock diet can accelerate 
gonadal maturation (Nainggolan et al., 2014). Another study showed that Oodev combined with Indigofera zollingeriana plants able to accelerate gonadal maturation also increase protein levels and lower fat levels especially cholesterol in grass carp (Ctenopharyngodon idella) fish gonad (Mulyasih et al., 2016).

Carotenoids suspected ingredient contained in Spirulina platensis and Indigofera zollingeriana that collaborate with Oodev hormones in accelerating gonadal maturation. Fish not only store carotenoids in integument but also accumulate in their gonads, which can improve ovarian development and fertilization. Polar carotenoids preferentially absorb more in many species of fish, particularly astaxanthin rather than canthaxanthin, zeaxanthin or carotenes (GarcíaChavarría \& Lara-Flores, 2013). Carotenoids particularly astaxanthin are recognized to be involved in the reproductive processes of many organisms due to their accumulation within reproductive organs. It has been claimed that astaxanthin triggers a speedier oocyte maturation in rainbow trout (Lim et al., 2017).

Considering biological function and role of Oodev hormone and astaxanthin in the reproductive cycle of fish, the objective of the present research was to investigate whether reproductive characteristics such gonadal maturation and percentage of maturation were correlated with the dietary of Oodev hormone and astaxanthin toward female North African catfish broodstock.

\section{MATERIALS AND METHODS}

The experiment was conducted at The Aquaculture Development of Pangasius and Clarias Catfish (ADPCC) Station of Marine and Fisheries Department of West Java Province (Subang, Indonesia) from August to November 2017. In order to compare diets from various amounts of Oodev hormone and astaxanthin with the control diet, nine treatments were designated for the study.

One-year-old of female Mutiara strain North African catfish from ADPCC with an average body weight of $550 \pm 45.22 \mathrm{~g}$ were used as broodstock. The fish were tagged and randomly distributed into nine outdoor walled concrete ground based tanks $\left(2 \times 1.5 \times 1.5 \mathrm{~m}^{3}\right)$ with a total of 360 female distributed in nine tanks (40 fish in each tank). Before the treatment, the fish were adapted for two weeks and fed with control diet twice a day (09.00 am and $16.00 \mathrm{pm}$ ) for $2 \%$ of biomass per day. Water quality status was daily examined as follow: temperature between $25-28.7^{\circ} \mathrm{C}, \mathrm{pH}$ between 6.6-7.8, dissolved oxygen between 4-6.5 $\mathrm{mg} / \mathrm{L}$, and ammonia between $0.01-0.09 \mathrm{mg} / \mathrm{L}$.

The Method used in this study was the experimental model using completely randomize design (Table 1). Three different dosages of Oodev hormone in fish feed: $0,0.5$ and $1 \mathrm{~mL} /$

Table 1. Research experimental design*

\begin{tabular}{cccc}
\hline \multirow{2}{*}{$\begin{array}{c}\text { Astaxanthin } \\
(\mathrm{mg} / \mathrm{kg} \text { feed })\end{array}$} & \multicolumn{3}{c}{ Oodev (mL/kg fish for 2 weeks) } \\
\cline { 2 - 4 } & 0 & 0.5 & 1 \\
\hline 0 & $\mathrm{C}$ & Od0.5 & Od1 \\
50 & A50 & Od0.5A50 & Od1A50 \\
100 & A100 & Od0.5A100 & Od1A100 \\
\hline
\end{tabular}

Note: ${ }^{*} \mathrm{C}$ is Control with $0 \mathrm{~mL} / \mathrm{kg}$ Oodev and $0 \mathrm{mg} /$ $\mathrm{kg}$ Astaxanthin, Od0.5 consisted of $0.5 \mathrm{~mL} / \mathrm{kg}$ Oodev and $0 \mathrm{mg} / \mathrm{kg}$ astaxanthin, Od1 consisted of $1 \mathrm{~mL} / \mathrm{kg}$ Oodev and $0 \mathrm{mg} / \mathrm{kg}$ astaxanthin, A50 consist of 0 $\mathrm{mL} / \mathrm{kg}$ Oodev and $50 \mathrm{mg} / \mathrm{kg}$ astaxanthin, Od0.5A50 consist of $0.5 \mathrm{~mL} / \mathrm{kg}$ Oodev and $50 \mathrm{mg} / \mathrm{kg}$ astaxanthin, Od1A50 consisted of $1 \mathrm{~mL} / \mathrm{kg}$ Oodev and $50 \mathrm{mg} / \mathrm{kg}$ astaxanthin, A100 consisted of $0 \mathrm{~mL} / \mathrm{kg}$ Oodev and 100 $\mathrm{mg} / \mathrm{kg}$ astaxanthin, Od0.5A100 consisted of $0.5 \mathrm{~mL} / \mathrm{kg}$ Oodev and $100 \mathrm{mg} / \mathrm{kg}$ astaxanthin, Od1A100 consisted of $1 \mathrm{~mL} / \mathrm{kg}$ Oodev and $100 \mathrm{mg} / \mathrm{kg}$ astaxanthin.

$\mathrm{kg}$ of broodstock for two weeks, and second was three different dosages of astaxanthin supplement in fish feed: 0, 50, and $100 \mathrm{mg} / \mathrm{kg}$ feed.

\section{Preparation of experimental diet}

The experimental diet ware performed by using commercial fish pellets (36\% protein, 5 $\%$ fat, $4 \%$ fiber, $10 \%$ ash, and $11 \%$ moisture) which were enriched with Oodev hormone and astaxanthin. The hormone added to the feed was Oodev (oocyte developer) which is a developed hormone product from Reproduction and Genetics Laboratory of Aquaculture Department of Bogor Agricultural University. Oodev contains PMSG and anti-dopamine. The administered dosage of Oodev was $0,0.5$ and $1 \mathrm{~mL} / \mathrm{kg}$ of fish for two weeks. Astaxanthin was as Carophyll ${ }^{\circledR}$ pink $10 \%$ DSM Nutrition and the administered dosage was 0,50 and $100 \mathrm{mg} / \mathrm{kg}$ of feed. Astaxanthin obtained from The Research Institute for Ornamental Fish Aquaculture of Ministry of Marine Affairs and Fisheries of the Republic of Indonesia (BRPIH Depok).

The process of feed coating was started with the addition of water to designated amount of 
Oodev and astaxanthin and sprayed to the commercial feed. Furthermore, carboxymethyl cellulose (CMC) powder was added as a binder $1 \%$ of commercial feed to the commercial feed mix with Oodev and/ or astaxanthin on the surface layer of the feed. The feed was then dried indoor for two hours at $27{ }^{\circ} \mathrm{C}$. The prepared feeds were put into container and kept in room temperature. The feed preparation process was performed once in two weeks and given $2 \%$ of biomass per day for 12 weeks.

\section{Reproductive parameters measurement}

Measurements of fish body, gonad and liver weights were performed at weeks $0,2,4,6,8,10$ and 12. The measurement of gonad and liver weights was to calculate the gonadosomatic (GSI) and hepatosomatic (HSI) indexes. Gonads and liver are obtained by dissections of four broodstock in every two weeks for each treatment. Gonads and hearts are then weighed in digital scales. The index were calculated according to formula by Tyor and Pahwa (2017) as following:

$$
\begin{aligned}
& \text { GSI }(\%)=\frac{\text { Gonad weight }}{\text { Fish body weight }} \times 100 \\
& \text { HSI }(\%)=\frac{\text { Liver weight }}{\text { Fish body weight }} \times 100
\end{aligned}
$$

Measurement of eggs diameter was performed by cannulation using catheter with 100 egg samples per treatment. Eggs samples were fixed in formaldehyde alcohol acetic acid (FAA) solution with ratio of 6:3:1, microscope and digital ocular micrometer of Olympus AnalySIS Image Processing v. 5.1 software were used to determine the eggs diameter. The measurement of eggs diameter has been performed at
Research Institute for Fish Breeding, SukamandiWest Java.

The rematuration period was measured after the broodstock that has been tagged mature then spawned until the same broodstock mature again. The length of rematuration time was observed weekly for 12 weeks during the raising 20 broodstocks for each treatment.

\section{Data analysis}

The obtained results were compared based on mean number of replications and with the inclusion of standard error of measurement. Periods and length of rematuration were described by descriptive statistic. Whereas, analysis of GSI, HSI, eggs diameter, and total fecundity were performed using one-way analysis of variance to compare the data. In order to find out whether or not there was any significant difference (if any) between the means, Tukey test was used, at $\mathrm{P}<0.05$ level of significance.

\section{RESULTS AND DISCUSSION}

\section{Results}

\section{The broodstock growth}

The average body weight are presented on Table 2. The average body weight of matured female Mutiara strain catfish two-weekly showed an increasing trend on all treatments during 12 weeks of observation. However, the average body weight between treatments in the same week showed no significant difference $(\mathrm{P}>0.05)$.

\section{Gonadal somatic and hepatosomatic indexes}

Gonadal somatic index (GSI) is an indicator of broodstock gonadal and maturity level

\begin{tabular}{|c|c|c|c|c|c|c|c|}
\hline \multirow{2}{*}{ Treatment } & \multicolumn{7}{|c|}{ Average body weight $(\mathrm{g})$ week of ${ }^{* *}$} \\
\hline & 0 & $2^{\text {nd }}$ & $4^{\text {th }}$ & $6^{\text {th }}$ & $8^{\text {th }}$ & $10^{\text {th }}$ & $12^{\text {th }}$ \\
\hline $\mathrm{C}$ & $568 \pm 45.37^{\mathrm{a}}$ & $699 \pm 25.45^{\mathrm{a}}$ & $817 \pm 36.74^{a}$ & $949 \pm 36.95^{\mathrm{a}}$ & $1.10 \pm 26.31^{\mathrm{a}}$ & $1.24 \pm 43.75^{\mathrm{a}}$ & $1.35 \pm 35.55^{\mathrm{a}}$ \\
\hline A50 & $578 \pm 42.66^{\mathrm{a}}$ & $697 \pm 36.37^{a}$ & $811 \pm 36.63^{\mathrm{a}}$ & $946 \pm 41.37^{\mathrm{a}}$ & $1.08 \pm 47.42^{\mathrm{a}}$ & $1.22 \pm 35.61^{\mathrm{a}}$ & $1.34 \pm 28.43^{\mathrm{a}}$ \\
\hline A100 & $572 \pm 42.77^{a}$ & $705 \pm 27.66^{\mathrm{a}}$ & $807 \pm 30.88^{a}$ & $942 \pm 39.61^{\mathrm{a}}$ & $1.08 \pm 39.27^{\mathrm{a}}$ & $1.23 \pm 55.14^{\mathrm{a}}$ & $1.34 \pm 30.45^{\mathrm{a}}$ \\
\hline Od0.5 & $582 \pm 50.19^{a}$ & $704 \pm 30.20^{\mathrm{a}}$ & $834 \pm 45.50^{a}$ & $965 \pm 22.20^{\mathrm{a}}$ & $1.08 \pm 44.42^{\mathrm{a}}$ & $1.22 \pm 37.89^{a}$ & $1.34 \pm 27.38^{\mathrm{a}}$ \\
\hline Od1 & $559 \pm 45.25^{\mathrm{a}}$ & $717 \pm 29.40^{a}$ & $811 \pm 46.46^{\mathrm{a}}$ & $947 \pm 41.81^{\mathrm{a}}$ & $1.06 \pm 43.58^{\mathrm{a}}$ & $1.23 \pm 36.04^{\mathrm{a}}$ & $1.33 \pm 33.88^{\mathrm{a}}$ \\
\hline Od0.5A50 & $563 \pm 44.68^{a}$ & $702 \pm 26.47^{a}$ & $821 \pm 38.45^{\mathrm{a}}$ & $954 \pm 43.38^{\mathrm{a}}$ & $1.08 \pm 40.77^{\mathrm{a}}$ & $1.23 \pm 36.88^{a}$ & $1.34 \pm 25.88^{a}$ \\
\hline Od0.5A100 & $559 \pm 39.67^{a}$ & $710 \pm 26.91^{\mathrm{a}}$ & $814 \pm 33.20^{\mathrm{a}}$ & $943 \pm 43.79^{a}$ & $1.08 \pm 38.59^{\mathrm{a}}$ & $1.22 \pm 46.04^{\mathrm{a}}$ & $1.35 \pm 25.46^{\mathrm{a}}$ \\
\hline Od1A50 & $578 \pm 40.11^{\mathrm{a}}$ & $708 \pm 30.80^{a}$ & $814 \pm 37.62^{a}$ & $930 \pm 40.23^{a}$ & $1.08 \pm 43.73^{\mathrm{a}}$ & $1.22 \pm 44.67^{\mathrm{a}}$ & $1.35 \pm 30.52^{\mathrm{a}}$ \\
\hline Od1A100 & $575 \pm 46.12^{\mathrm{a}}$ & $705 \pm 23.62^{\mathrm{a}}$ & $809 \pm 35.20^{a}$ & $950 \pm 40.92^{\mathrm{a}}$ & $1.08 \pm 42.10^{\mathrm{a}}$ & $1.22 \pm 45.69^{a}$ & $1.34 \pm 32.90^{a}$ \\
\hline
\end{tabular}

Table 2. Average body weight of experimental fish two-weekly

*Note: $\mathrm{C}=\mathrm{Control}, \mathrm{A}=$ Astaxanthin, $\mathrm{Od}=$ Oodev. Number= dose; ** The same superscript letter in the same column indicate no significant differences between treatments in the same week $(\mathrm{P}>0.05)$. 
development that will increase when the fish has matured and dropped drastically thereafter. The GSI is also used to study the spawning period. Whereas the hepatosomatic index (HSI) is an indicator of vitellogenesis process in the liver where it produces vitellogenin as yolk egg formers (Muddasir \& Neelofar, 2017).

The GSI values are shown in Figure 1. From figure 1 above, it can be seen that the GSI values of all treatments were not significantly different $(\mathrm{P}>0.05$ ) before the treatment was given (week 0). However, GSI values were significantly different $(\mathrm{P}<0.05)$ on the $2^{\text {nd }}$ week to the $12^{\text {th }}$ week. The variation of GSI value began to be seen since the $2^{\text {nd }}$ week with the highest peak starting at the $4^{\text {th }}$ week on Od1A100 $(1 \mathrm{~mL} / \mathrm{kg}$ broodstock of Oodev for two weeks and $100 \mathrm{mg} / \mathrm{kg}$ feed of astaxanthin) treatment of $20.00 \pm 0.22 \%$, while the lowest GSI peak value at the $4^{\text {th }}$ week of the control was 7.62 $\pm 0.33 \%$. The combination of the Od1A100 $(1 \mathrm{~mL} / \mathrm{kg}$ broodstock of Oodev for two weeks and $100 \mathrm{mg} / \mathrm{kg}$ feed of astaxanthin) treatment resulted the highest GSI value, with three peaks, at the $4^{\text {th }}$, 8 th and $12^{\text {th }}$ weeks, with the highest values peak at the $4^{\text {th }}$ week, while the highest peak of the control only occurred at the $6^{\text {th }}$ week by $12.62 \pm 0.15 \%$.

The HSI values are shown in Figure 2. From figure 2 above, it can be seen that the HSI values of all treatments were not significantly different $(\mathrm{P}>$ 0.05 ) before the treatment was given (week 0 ), t. However, the values of HSI were significantly different $(\mathrm{P}<0.05)$ from the $2^{\text {nd }}$ week to the $12^{\text {th }}$ week.

The variations of HSI value also began to be seen since the $2^{\text {nd }}$ week with the highest level on the Od1A100 $(1 \mathrm{~mL} / \mathrm{kg}$ Broodstock of Oodev for two weeks and $100 \mathrm{mg} / \mathrm{kg}$ feed of astaxanthin) treatment of $1.88 \pm 0.06 \%$ and the lowest HSI value at the $2^{\text {nd }}$ week on the control was $1.02 \pm 0.07$ $\%$. The combination of Oodev and astaxanthin on the Od1A100 treatment also made the highest HSI value with three peaks, namely at the $2^{\text {nd }}, 8^{\text {th }}$, and $12^{\text {th }}$ weeks, with the highest value of the peak at the $12^{\text {th }}$ week of $2.00 \pm 0.10 \%$, while in control, the highest peak at the $6^{\text {th }}$ week of $1.5 \pm 0.02 \%$. The increase of HSI value is due to the synthesis and secretion of vitellogenin in the liver.

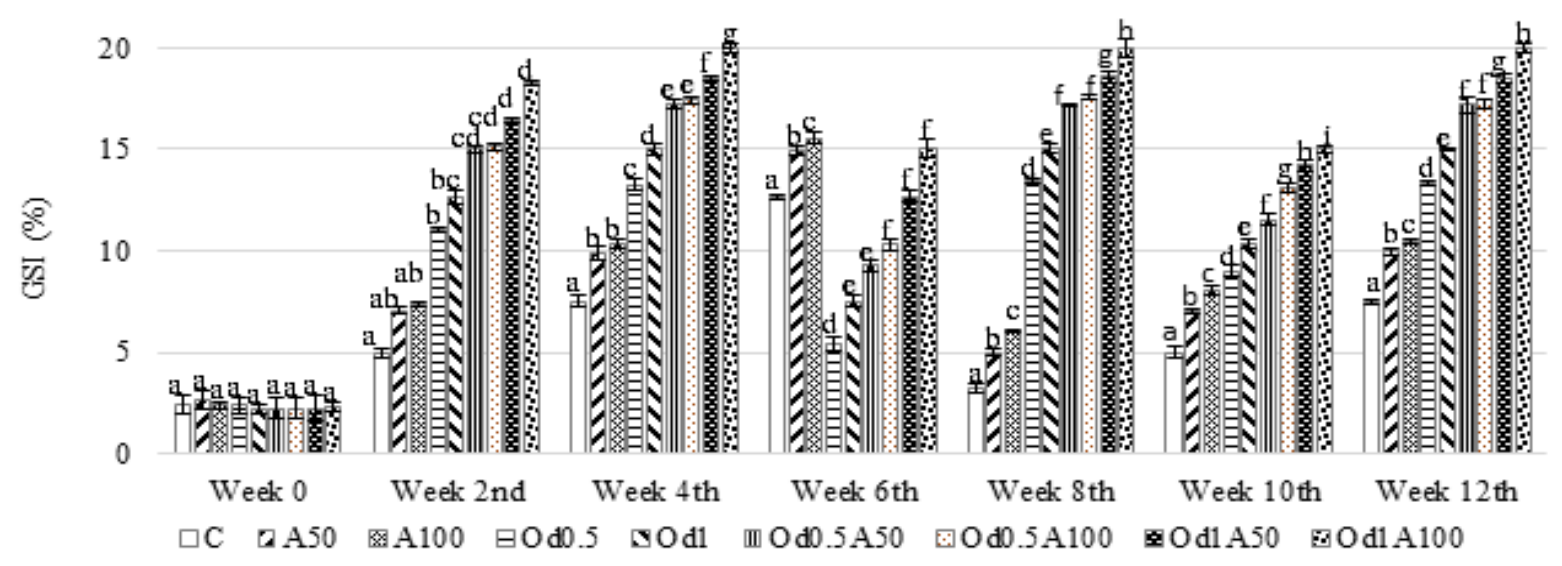

Figure 1. Two-weekly gonadal somatic index (GSI) result of Oodev and astaxanthin feed induction. The treatment code: $\mathrm{C}=$ control, $\mathrm{A}=$ astaxanthin, $\mathrm{Od}=$ oodev and number= dose. The different letters on top of the bar indicate significant differences between treatments in the same week $(\mathrm{P}<0.05)$.

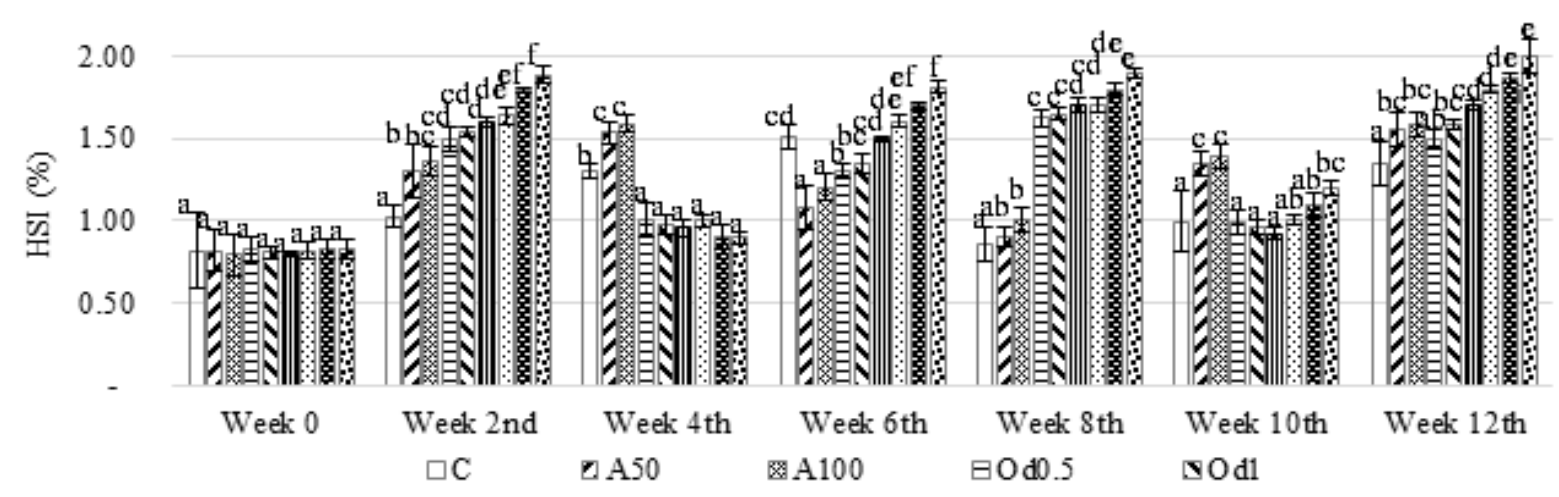

Figure 2 Two-weekly hepatosomatic index (HSI) result of Oodev and astaxanthin feed induction. The treatment code: $\mathrm{C}=$ Control, $\mathrm{A}=$ Astaxanthin, $\mathrm{Od}=\mathrm{Oodev}$ and number=dose. The different letters on top of the bar indicate significant differences between treatments in the same week $(\mathrm{P}<0.05)$. 


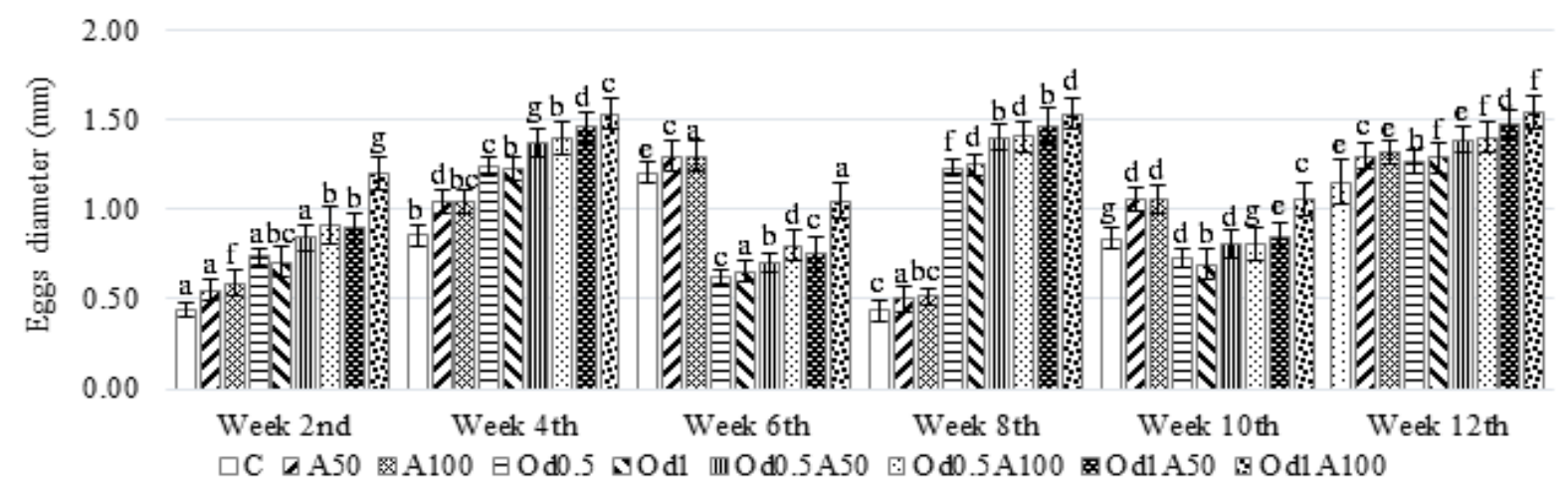

Figure 3. Two-weekly eggs diameter result of Oodev and astaxanthin feed induction. The treatment code: $\mathrm{C}=$ control, $\mathrm{A}=$ astaxanthin, $\mathrm{Od}=$ oodev and number= dose. The different letters on top of the bar indicate significant differences between treatments in the same week $(\mathrm{P}<0.05)$.

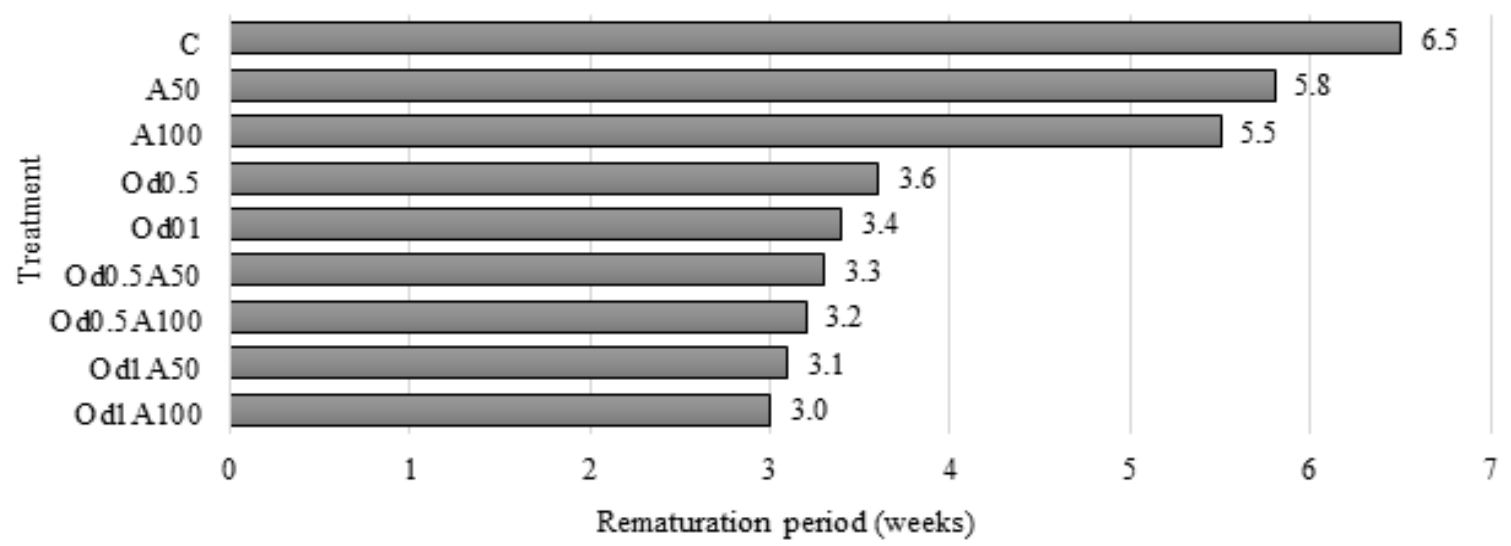

Figure 4. The rematuration average period of Oodev and astaxanthin feed induction. The treatment code: $\mathrm{C}=$ control, $\mathrm{A}=$ astaxanthin, $\mathrm{Od}=$ oodev and number= dose. The observed amount was 20 fishes each treatment

\section{The diameter of the eggs}

Eggs diameter of all treatments in the same week was significantly different $(\mathrm{P}<0.05)$ and increased with the increasing of rearing times until spawned. The largest rapid growing eggs diameter occurred in Od1A100 (1 $\mathrm{mL} / \mathrm{kg}$ broodstock of Oodev for two weeks and $100 \mathrm{mg} /$ $\mathrm{kg}$ feed of astaxanthin) treatment which the peak started since the $4^{\text {th }}$ week $(1.54 \pm 0.087 \mathrm{~mm})$ and then rose again in the $6^{\text {th }}$ week $(1.53 \pm 0.097 \mathrm{~mm})$ and the highest at the $12^{\text {th }}$ week $(1.55 \pm 0.090 \mathrm{~mm})$. While the slowest and the smallest growing eggs diameter occurred in the control with the peak at the $6^{\text {th }}$ week of $1.21 \pm 0.058 \mathrm{~mm}$. According to Iswanto et al. (2016) the eggs diameter of ready-to-breed Mutiara strain catfish is between 1.20-1.54 mm. The eggs diameter observation result is shown in Figure 3.

\section{Rematuration period and proportion of mature broodstock}

The result of average rematuration period and proportion of mature broodstock over 12 weeks of observation are presented in Figure 4 and Table 3 , respectively. The fastest average rematuration period occurred in Od1A100 $(1 \mathrm{~mL} / \mathrm{kg}$ broodstock of Oodev for two weeks and $100 \mathrm{mg} / \mathrm{kg}$ feed of astaxanthin) treatment which only takes three weeks to remature after breeding with the high proportion of mature broodstock $(90 \%)$. While the longest average rematuration period occurred in controls which take 6.5 weeks to remature after breeding with the average proportion of mature broodstock at the $6^{\text {th }}$ week only $55 \%$.

\section{Discussion}

The results observations of Mutiara catfish body weight on all treatments showed every two weeks (Table 2). However, body weight increased was not significantly different in all treatments at the same week. Thus, indicating that all of Mutiara strain catfish in each treatment were fulfilled their energy needs through feeding evenly distributed. Nevertheless, the results showed that the reproduction performance between treatments were significantly different. This indicates that 
Table 3. Weekly proportion of mature broodstock

\begin{tabular}{ccccccccccc}
\hline \multirow{2}{*}{ Treatment } & \multicolumn{8}{c}{ Proportion of mature broodstock (\%) week of } \\
\cline { 2 - 11 } & $3^{\text {rd }}$ & $4^{\text {th }}$ & $5^{\text {th }}$ & $6^{\text {th }}$ & $7^{\text {th }}$ & $8^{\text {th }}$ & $9^{\text {th }}$ & $10^{\text {th }}$ & $11^{\text {th }}$ & $12^{\text {th }}$ \\
\hline C & - & - & - & 55 & 45 & - & - & - & - & - \\
A50 & - & - & 35 & 55 & 10 & - & - & - & - & - \\
A100 & - & - & 55 & 35 & 10 & - & - & - & - & - \\
Od0.5 & 40 & 30 & 10 & 15 & 65 & 10 & 5 & 45 & 40 & 15 \\
Od01 & 65 & 35 & - & 25 & 65 & 5 & 5 & 70 & 25 & - \\
Od0.5A50 & 80 & 20 & - & 50 & 40 & 10 & 15 & 70 & 15 & - \\
Od0.5A100 & 80 & 20 & - & 70 & 25 & 5 & 65 & 25 & 10 & - \\
Od1A50 & 85 & 10 & 5 & 70 & 25 & 5 & 70 & 25 & 5 & - \\
Od1A100 & 90 & 10 & - & 90 & 10 & - & 90 & 10 & - & - \\
\hline
\end{tabular}

Notes: $\mathrm{C}=$ control, $\mathrm{A}=$ astaxanthin, $\mathrm{Od}=$ oodev. Number $=$ dose.

the energy derived from the feed were used differently in each treatment. The energy will be utilized for growth or reproduction. The increase in weight also influenced by the process of gonadal development affecting energy consumption, thus requiring more energy for gamete formation on the broodstock.

The value of GSI in Mutiara strain catfish appears to be different in each treatment. GSI values for 12 weeks of observation provide a fluctuating pattern, which tends to increase more rapidly than controls in all treatments using astaxanthin, Oodev or the combinations of both (Figure 2). The combination of $1 \mathrm{~mL} / \mathrm{kg}$ broodstock of Oodev for 2 weeks and $100 \mathrm{mg} /$ $\mathrm{kg}$ astaxanthin on feed showed the highest GSI value compared to all other treatments with three peaks occurred in the $4^{\text {th }}, 8^{\text {th }}$ and $12^{\text {th }}$ week, with the highest peak values on the $4^{\text {th }}$ week $(20.00 \pm$ $0.22 \%$ ). These results is higher than common $C$. gariepinus, which were between 11.73-17.27\% (AlDeghayem et al., 2017). This suggests that the higher doses of Oodev combined with astaxanthin will further increase the value of GSI. This result is also higher when compared with other reports that also use Oodev and spirulina that contained carotenoids, the peak of Clarias sp. GSI value is between $7.75-11.31 \%$ on day 40 or week six after spawn (Nainggolan et al., 2014).

The lower doses of Oodev and astaxanthin combined resulted in the lower GSI value obtained, although it still appears to have three peaks. While in the control appear to have the lowest GSI value and only one peak that occurs in the $6^{\text {th }}$ week with $12.62 \pm 0.15 \%$. The rapid increase in the GSI especially on Oodev induced treatment was caused by the influence of PMSG and $\mathrm{AD}$ contained in Oodev can increase the expression of FSH and aromatase enzymes as well as GSI (Rafiuddin, 2014).

Such as the GSI value, the HSI values also fluctuate from the beginning to the end of the treatment, but the HSI value tends to increase and reach the peak faster than the GSI value, and its value falls as the GSI value reaching its peak in all treatments. Consistent with the GSI value, the highest HSI value also occurred in the combination of $1 \mathrm{~mL} / \mathrm{kg}$ broodstock of Oodev for two weeks and $100 \mathrm{mg} / \mathrm{kg}$ feed of astaxanthin treatment with three peaks at the $2^{\text {nd }}, 8^{\text {th }}$ and $12^{\text {th }}$ week. Increased in HSI level indicates the growth of liver during maturation. The liver was induced by the increased of FSH due to Oodev hormone stimulation where the liver is a place to synthesize vitellogenin as the yolk eggs forming (Marina et al., 2008).

The increased treatment affects not only GSI and HSI values, but also occurs in rapidly growing of egg diameter (Figure 3). The study showed consistent results from several test parameters, including the egg diameter parameters obtained from the combination of $1 \mathrm{~mL} / \mathrm{kg}$ broodstock of Oodev for two weeks and $100 \mathrm{mg} / \mathrm{kg}$ feed of astaxanthin, which delivered the best results that can make faster and larger growth in egg diameter. Aside from being influenced by hormonal stimulation, this cannot be separated from the role of astaxanthin. As can be seen that the best results are not only due to hormonal stimulation, but it is a combination of hormonal stimulation from Oodev hormone and astaxanthin. This was similar as described by Lim et al. (2017) that 
astaxanthin triggers a speedier oocyte maturation. The same thing is reported to occur in goldfish Carassius auratus with bigger egg diameter when compared with those without astaxanthin (Tizkar et al., 2013).

Fish cannot synthesize carotenoids such as astaxanthin, so it is essential to be incorporated into the diet (García-Chavarría \& Lara-Flores, 2013). Carotenoids are hydrophobic compounds that are not easily solubilized in the aqueous environment of the gastrointestinal tract of fish. Therefore, digestion, absorption and transport processes are associated to lipids (Das \& Biswas, 2016). Fish carotenoids are mostly transported to peripheral tissues by high density lipoproteins (HDL) and to a limited extent by low density lipoproteins (LDL). In rainbow trout and other Oncorhynchus species, astaxanthin and were found to be present in all serum lipoprotein fractions. In mature female fish, significant amounts of carotenoids also bind to vitellogenin, a female specific serum lipoprotein. During sexual maturation of Oncorhynchus keta, HDL and vitellogenin were associated with carotenoid transport during redistribution of carotenoids from muscle to the integument, and from muscle to ovaries, respectively (García-Chavarría \& Lara-Flores, 2013).

There are two sources of astaxanthin production, which is natural and synthetic sources. The natural sources of astaxanthin are algae, yeast, salmon, trout, krill, shrimp and crayfish. Whereas synthetic astaxanthin is produced through chemical synthesis (Ambati et al., 2014). The synthetic form is used predominantly for animal feed (Nguyen, 2013). the use of synthetic astaxanthin (100 mg astaxanthin/ $\mathrm{kg}$ fish feed) does not pose a significant additional risk to the environment compared with natural astaxanthin (EFSA, 2014). Similar to astaxanthin, PMSG hormone is also harmless because it is an organic compound from pregnant mare's serum (Rensis \& López-Gatius, 2014).

The improvement of reproductive performance that seen from GSI and HSI value also the egg diameter of Mutiara strain catfish broodstock due to administration of Oodev hormone and astaxanthin. Consistent with other result, the fastest average period of rematuration occurred in Od1A100 $(1 \mathrm{~mL} / \mathrm{kg}$ broodstock of Oodev for two weeks and $100 \mathrm{mg} / \mathrm{kg}$ feed of astaxanthin) treatment, which only take three weeks to remature after breeding with the proportion of mature broodstock is reaching 90\% This is twice faster than common Mutiara strain catfish rematuration period which usually takes 1.5 months or 6.5 weeks after spawning (Iswanto et al., 2016). These results are also faster than those reported using PMSG hormones and spirulina in C. gariepinus that can only accelerate the rematuration period to four weeks with the proportion of mature broodstock of $80 \%$ (Mayasari et al., 2012).

\section{CONCLUSION}

Combination of $1 \mathrm{~mL} / \mathrm{kg}$ broodstock of Oodev hormone for two weeks and $100 \mathrm{mg} /$ $\mathrm{kg}$ feed of astaxanthin diet showed the best result in accelerating rematuration period of the Mutiara catfish, up to three times faster and increased the proportion of mature broodstock up to $35 \%$, compared to control. The reproductive performance improvement of this combination is characterized by faster and higher increases in HSI and GSI values, the fastest growth of eggs diameter, accelerating the rematuration period, as well as the increased proportion of mature broodstock.

\section{REFERENCES}

Al-Deghayem WA, Al-Balawi1 HM, Kandeal1 SA, Suliman EA. 2017. Gonadosomatic index and some hematological parameters in African catfish Clarias gariepinus (Burchell, 1822) as affected by feed type and temperature level. Brazilian Archives of Biology and Technology 60: e160157.

Ambati RR, Phang SM, Ravi S, Aswathanarayana RG. 2014. Astaxanthin: sources, extraction, stability, biological activities and its commercial applications-a review. Marine Drugs 12: 128-152.

Bryant AS, Greenwood AK, Juntti SA, Byrne AE, Fernald RD. 2016. Dopaminergic inhibition of gonadotropin-releasing hormone neurons in the cichlid fish Astatotilapia burtoni. Journal of Experimental Biology 219: 3861-3865.

Dadebo E, Gebre-Mariam Z, Mengistou S. 2011. Breeding season, naturation, fecundity and condition factor of the African catfish Clarias gariepinus Burchell 1822 (Pisces: Clariidae) in Lake Chamo, Ethiopia. Ethiopian Journal of Biological Sciences 10: 1-17.

Das AP, Biswas SP. 2016. Carotenoids and pigmentation in ornamental Fish. Journal of 
Aquaculture \& Marine Biology 4: 00093.

De Graaf GJ, Janseen J. 1996. The artificial reproduction and pond rearing of the African catfish Clarias gariepinus in Sub-Saharan Africa. FAO. 1996. Handbook on The Artificial Reproduction and Pond Rearing of The African catfish Clarias Gariepinus in Sub-Saharan Africa. Rome: FAO.

Dufour S, Sebert ME, Weltzien FA, Rousseau K, Pasqualini C. 2010. Neuroendocrine Control by dopamine of teleost reproduction. Journal of Fish Biology 76:129-160.

[EFSA] European Food Safety Authority. 2014. Scientific Opinion on the safety and efficacy of synthetic astaxanthin as feed additive for salmon and trout, other fish, ornamental fish, crustaceans and ornamental birds. EFSA Journal 12: 3724.

García-Chavarría M, Lara-Flores M. 2013. The Use of carotenoid in aquaculture. Research Journal of Fisheries and Hydrobiology 8: 38-49.

Iswanto B, Suprapto R, Marnis H, Imran. 2016. Reproductive performance of Mutiara strain of African catfish Clarias gariepinus. Aquculture Media 11: 1-9

Lim KC, Yusoff FM, Shariff M, Kamarudin MS. 2017. Astaxanthin as feed supplement in aquatic animals. Reviews in Aquaculture 10: $1-36$

Mañanós E, Duncan N, Mylonas CC. 2008. Reproduction and Control of Ovulation, Spermiation and Spawning in Cultured Fish. In: Cabrita E, Robles V, Herráez MP, editor. Methods in Reproductive Aquaculture: Marine and Freshwater Species. Florida (US): CRC Press, Taylor and Francis Group. pp. 3-80.

Marina P, Salvatore V, Maria MDF, Franca R., Giuseppina DG, Maurizio R, Piero A. 2008. Effect of 17beta-estradiol and progesterone on vitellogenesis in the spotted ray Torpedo marmorata Risso 1810 (Elasmobranchii: Torpediniformes): studies on females and on estrogen-treated males. General and Comparative Endocrinology 157: 125-132.

Mayasari N, Sudrajat AO, Chrismada T. 2012. Induction of gonadal maturation in female catfish (Clarias sp.) with PMSG hormone and spirulina [Thesis]. Bogor: Institut Pertanian Bogor.

[MMAF] Ministry of Marine Affairs and Fisheries of The Republic of Indonesia. 2015. Performance Report of Directorate General of
Aquaculture 2014. Jakarta, Indonesia: KKP.

Muddasir J, Neelofar J. 2017. Studies on The Fecundity (F), Gonadosomatic Index (GSI), and Hepatosomatic Index (HSI) of Salmo trutta fario (brown trout) at Kokernag Trout Fish Farm, Anantnag, Jammu and Kashmir. International Journal of Fisheries Aquatic Studies 5: 170-173.

Mulyasih D, Sudrajat AO, Abdullah L. 2016. Maturational induction of grass carp, Ctenopharyngodon idella (Valenciennes, 1844) using hormone and Indigofera zollingeriana feed. Journal of Indonesian Ichthyology 16: 57-66.

Mylonas CC, Fostier A, Zanuy S. 2010. Broodstock management and hormonal manipulations of fish reproduction. General and Comparative Endocrinology 165: 516-534.

Nainggolan A, Sudrajat AO, Utomo BP, Harris E. 2014. Ovarian maturation in Asian catfish Clarias sp. by combination Oodev and nutrition addition spirulina plantesis. International Journal of Sciences: Basic and Applied Research 15: 564-583.

Nguyen KD. 2013. Astaxanthin: A Comparative Case of Synthetic VS. Natural Production. Chemical and Biomolecular Engineering: 94.

Rafiuddin A. 2014. Characterization, Cloning and engineering of FSH gene expression in stripped catfish during early gonadal development [Thesis]. Bogor: Institut Pertanian Bogor.

Reading BJ, Sullivan CV. 2011. Vitelogenesis in fishes. In: Farrell AP, Editor. Encyclopedia of fish physiology: From Genome to Environment. San Diego: Academic Press.

Rensis FD, López-Gatius F. 2014. Use of equine chorionic gonadotropin to control reproduction of the dairy cow: A Review. Reproduction in Domestic Animals 49: 177-182.

Saadony SAM, Eldanasoury MA, Ali BA, Sharaf SM. 2014. Seasonal reproductive biology and artificial propagation of female African catfish Clarias gariepinus after hormonal stimulation. Journal of Animal, Poultry \& Fish Production 2: $21-31$.

Sudrajat AO, Rafiuddin MA, Budiardi T. 2016. Induction of Gonadal Maturation of Striped Catfish (Pangasianodon hypopthalmus) using Pregnant Mare's Serum Gonadotropin Hormone and Antidopamine. In: The 11th International Student Conference on Advance Science and Technology 2016. December 
8-9, 2016. Kumamoto, Japan. Kumamoto University: 5-4.

Tizkar B, Soudagar M, Bahmani M, Hosseini SA, Chamani M. 2013. The effects of dietary supplementation of astaxanthin and b-caroten on the reproductive performance and egg quality of female goldfish (Carassius auratus).
Caspian Journal of Environmental Sciences 11: 217-231.

Tyor AK, Pahwa K. 2017. Ovarian development of African sharptooth catfish (Clarias gariepinus, Burchell 1822) from Delhi segment of river Yamuna. Journal Fish Aquatic Science 12: 117-126. 